\title{
A new species of troglobitic Anatemnus (Pseudoscorpiones: Atemnidae) from the Pilbara bioregion of Australia
}

\author{
Jason B. Alexander', Mieke A.A. Burger ${ }^{2}$ and Mark S. Harvey ${ }^{2,3}$ \\ ${ }^{1}$ Biota Environmental Sciences, 1/228 Carr Place, Leederville, Western Australia 6007, Australia. \\ 2 Department of Terrestrial Zoology, Western Australian Museum, Locked Bag 49, Welshpool DC, \\ Western Australia 6986, Australia. \\ ${ }^{3}$ Research Associate, Division of Invertebrate Zoology, American Museum of Natural History, \\ 79th Street @ Central Park West, New York, New York 10024-5192, USA. Research Associate, \\ Department of Entomology, California Academy of Sciences, Golden Gate Park, San Francisco, \\ California 94103-3009 USA. Adjunct, School of Animal Biology, University of Western Australia, \\ Crawley, Western Australia 6009, Australia. Adjunct, School of Natural Sciences, Edith Cowan \\ University, Joondalup, Western Australia 6027, Australia.
}

\begin{abstract}
A new species of the pseudoscorpion genus Anatemnus, A. subvastus, is described from subterranean environments in the Pilbara bioregion of Western Australia. Like Oratemnus cavernicola from New South Wales, it lacks eye spots, and has slightly elongated appendages and pallid colouration. It is known from only a small area of less than $20 \mathrm{~km}^{2}$. We also attribute Oratemnus cavernicola to the genus Anatemnus, forming the new combination Anatemnus cavernicola (Beier, 1976), but note that the generic assignment of both species should be reviewed pending an assessment of all genera of Atemninae.
\end{abstract}

KEYWORDS: taxonomy, morphology, subterranean

\section{INTRODUCTION}

The semi-arid Pilbara bioregion of north-western Australia is a hotspot for subterranean biodiversity, with numerous new and distinctively modified troglobitic and stygobitic species being described over the past decade. Arthropods such as insects, arachnids and crustaceans dominate the fauna (Eberhard et al. 2005), with the arachnid fauna including schizomids (Harvey et al. 2008), spiders (Burger et al. 2010; Baehr et al. 2012) and pseudoscorpions (Harvey and Edward 2007; Harvey and Volschenk 2007; Edward and Harvey 2008; Harvey and Leng 2008a, 2008b). This fauna has generated much interest due to the interplay between the extraction of minerals, principally iron-ore, and conservation of a relictual and highly distinctive subterranean fauna.

Amongst samples collected from subterranean ecosystems in the Hamersley Range of the Pilbara bioregion were some unusual pseudoscorpions of the family Atemnidae with distinctly troglobitic facies including slender pedipalps and legs, pallid colour and no eyes. To better document the subterranean fauna of the region, we here describe this atemnid species. The atemnid fauna of continental Australia is restricted to just four species of Oratemnus Beier, 1932, O. cavernicola Beier, 1976, O. curtus (Beier, 1954), O. distinctus (Beier, 1948) and O. punctatus (L. Koch and Keyserling, 1885) (Beier 1948, 1954, 1966, 1976; Harvey 2013). The new species shows many similarities with $O$. cavernicola, particularly in the disposition of the trichobothria of the fixed chelal finger, which differs from the arrangement of other species of Oratemnus. Instead, the pattern is more reminiscent of species of Anatemnus Beier, 1932, and we suggest that both species can be accommodated in this genus.

\section{MATERIAL AND METHODS}

The holotype used in this study was collected from subterranean environments using baited colonisation traps, which are left suspended at depths through bore hole profiles for a minimum of six weeks. Traps were baited with locally sourced leaf litter material, which is soaked and irradiated to kill surface fauna and facilitate breakdown of the litter. Other specimens were collected by scraping a weighted net vertically up the sides of bore holes, which collects fauna utilising the side of the 


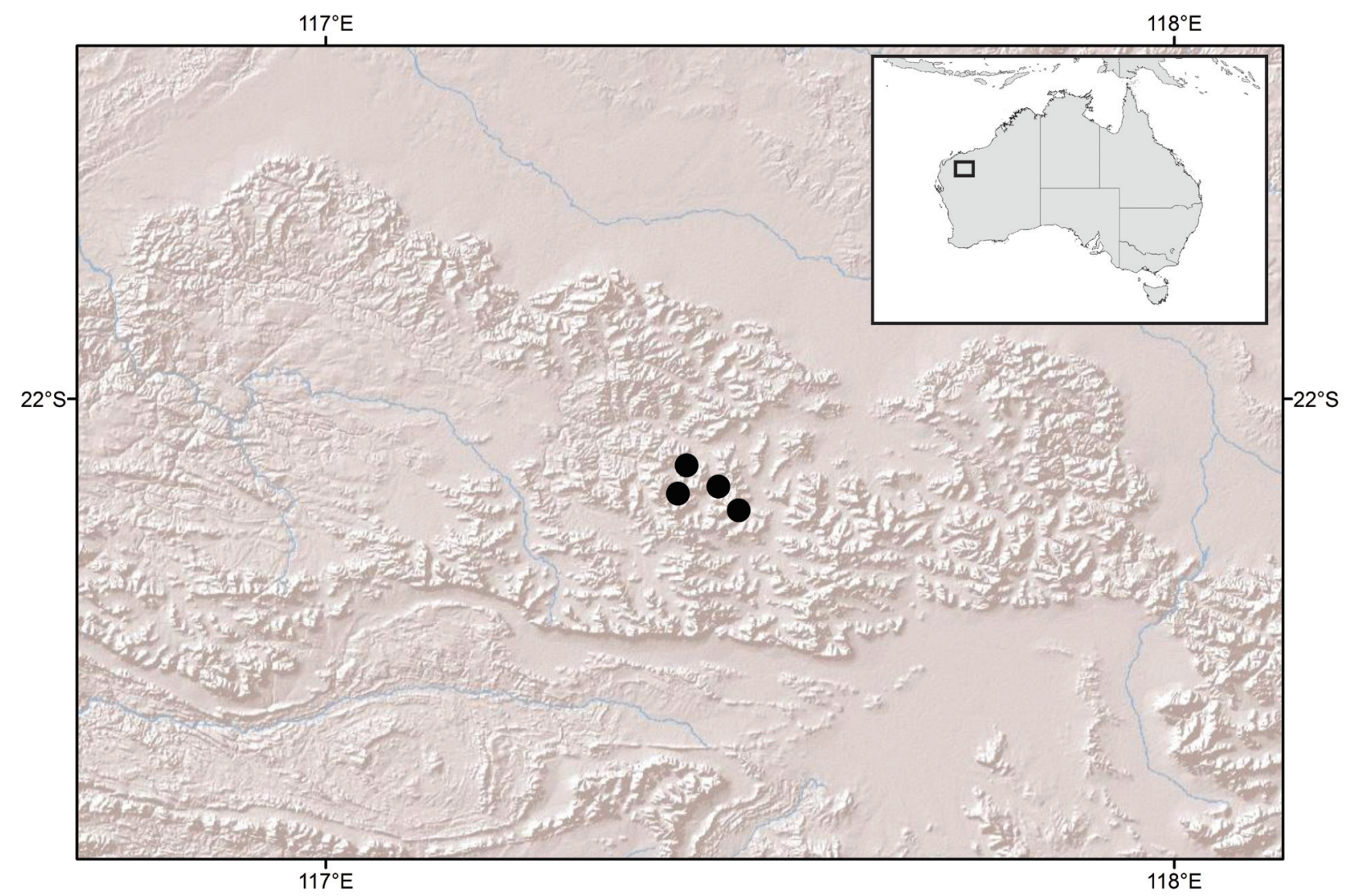

FIGURE 1 Known distribution of Anatemnus subvastus sp. nov.

bore (Halse and Pearson 2014). Collected specimens are lodged in the Western Australian Museum, Perth (WAM), and were examined using a temporary slide mount prepared by immersion of the specimens in $50 \%$ lactic acid at room temperature for several days. They were then mounted on a microscope slide with a $10 \mathrm{~mm}$ coverslip supported by small sections of 0.25 or $0.35 \mathrm{~mm}$ diameter nylon fishing line. After study the specimens were returned to $75 \%$ ethanol with the dissected portions placed in $12 \times 3 \mathrm{~mm}$ glass genitalia microvials (BioQuip Products, Inc.). Specimens were examined with a Leica MZ-16A dissecting microscope, and a Leica DM2500 compound microscope, the latter fitted with interference contrast, and illustrated with the aid of a drawing tube attached to the compound microscope. Measurements were taken at the highest possible magnification using an ocular graticule.

Terminology and mensuration mostly follow Chamberlin (1931), with the exception of the nomenclature of the pedipalps, legs and with some minor modifications to the terminology of the trichobothria (Harvey 1992), chelicera (Judson 2007) and faces of the appendages (Harvey et al. 2012). Morphological characters were scored using Open DELTA 1.0 (Atlas of Living Australia, Canberra, Australia) (Dallwitz et al. 1999 onwards), which was also used to generate a natural language description that was subsequently edited further.
Family Atemnidae Kishida, 1929

Subfamily Atemninae Kishida, 1929

Genus Anatemnus Beier, 1932

Anatemnus Beier 1932: 578.

\section{TYPE SPECIES}

Chelifer javanus Thorell, 1883, by original designation.

\section{REMARKS}

The genera of Atemninae are, in general, poorly defined and in need of reassessment and revision (Klausen 2005). Some of the features used by Beier (1932a, 1932b) when the generic classification was first established have since been shown to be of dubious utility. For example, Titanatemnus Beier, 1932 was separated from other genera mainly by its large size, and Catatemnus Beier, 1932, Metatemnus Beier, 1932, Stenatemnus Beier, 1932, and Tamenus Beier, 1932 were segregated from the other atemnine genera by the presence of a transverse furrow on the carapace (Beier 1932b). Klausen (2005) has since suggested that the presence of a furrow has been frequently misinterpreted in atemnids and is of dubious usefulness to separate genera. 
The new species described below, as well as O. cavernicola from New South Wales, have trichobothria it and isb widely spaced, with it either midway between $i s b$ and the tip of the finger, or with it closer to the tip than to isb. Only a few genera of Atemninae have species with this configuration including some species of Anatemnus Beier, 1932 and Catatemnus Beier, 1932, and all species of Mesatemnus Beier and Turk, 1952, Metatemnus Beier, 1932, Stenatemnus Beier, 1932, Synatemnus Beier, 1944 and Tamenus Beier, 1932 (e.g. Beier 1932b; Vachon 1938; Beier 1944, 1951a, 1951b; Beier and Turk 1952; Beier 1957, 1965; Muchmore 1972; Mahnert 1978). We suggest that this feature might be of some value in diagnosing genera of Atemninae, and accordingly place the new species and $O$. cavernicola amongst this group of genera. Not all species of Anatemnus and Catatemnus, however, have this arrangement. For example, A. luzonicus Beier, 1932, A. madecassus Beier, 1932, A. nilgiricus Beier, 1932, A. orites (Thorell, 1889), A. subindicus (Ellingsen, 1910), A. subvermiformis Redikorzev, 1938), A. tonkinensis Beier, 1943, C. braunsi (Tullgren, 1907) and C. comorensis (Ellingsen, 1910) have $i s b$ and it situated adjacent to each other or with it only slightly distal to isb (e.g. Beier 1932b, 1951a). It is currently difficult, or impossible, to adequately diagnose Mesatemnus, with the sole species M. cyprianus (Beier and Turk) from Cyprus, which was poorly described (Beier and Turk 1952) and has not since been redescribed. Likewise, the African genus Synatemnus is poorly characterized (Beier 1944).

Our decision to include the new subterranean species and $O$. cavernicola in Anatemnus is clearly provisional, but there appears to be nothing in the generic descriptions that precludes their inclusion in the genus (Beier 1932a, 1932b), and we are unable to suggest an alternative generic arrangement. For example, both species lack the gaping chelal fingers that are characteristic of Metatemnus (Beier 1932b, 1952; Muchmore 1972), they lack the long tarsal claws of Stenatemnus (Beier 1932b), and they lack the extremely distal position of $i t$ that is found in Tamenus.

Likewise, due to the position of trichobothria isb and it, they are unlikely to be included in Oratemnus, the only other atemnid genus currently recorded from mainland Australia. However, even this is somewhat confounded as the Australian species currently placed in this genus, O. curtus, O. distinctus and O. punctatus, lack the narrow pedicel of the pedipalpal patella found in the type species O. articulosus (Simon, 1899) which was originally used to define the genus (Beier 1932a, 1932b). The narrow pedicel occurs in other Australasian species such as O. boettcheri Beier, 1932, O. brevidigitatus Beier, 1940, O. confusus Murthy and Ananthakrishnan, 1977, O. manilanus Beier, 1932, O. proximus Beier, 1932, O. timorensis Beier, 1932 and O. yodai Morikawa, 1968 (e.g. Beier 1932a, 1932b, 1940; Morikawa 1968; Murthy and Ananthakrishnan 1977), but is lacking in other species including O. afghanicus
Beier, 1959, O. semidivisus (Redikorzev, 1938) and O. loyolai Sivaraman, 1980 from Asia, and O. samoanus Beier, 1932 from the Pacific region (e.g. Beier 1932a, 1932b; Redikorzev 1938; Beier 1948, 1954, 1959, 1976; Sivaraman 1980). To further confuse matters, it is possible that there might be slight sexual dimorphism in those species with narrow pedicels. The illustrations of O. samaonus by Chamberlin (1939) show the male with a slightly longer and thinner pedicel that the female, and those species with a more extenuated pedicel that were illustrated by Beier (1932b) all appear to be males rather than females.

Therefore, we attribute $A$. subvastus and Oratemnus cavernicola to the genus Anatemnus, forming the new combination Anatemnus cavernicola (Beier, 1976), but note that the generic assignment should be reviewed pending an assessment of all atemnine genera which are currently poorly defined and badly in need of redefinition (Klausen 2005). These are not the only Australian species of Anatemnus, as other species have been collected in rainforest habitats in eastern Australia (MSH, unpublished data). It is presumed that they represent undescribed species, but further work is needed on the atemnid fauna of Australia to adequately resolve their status.

\section{Anatemnus subvastus sp. nov.}

Figures 2-18

http://www.zoobank.org/urn:Isid:zoobank.
org:act:3AFA7219-5701-438D-A5D3-CAC872FF72F1

\section{MATERIAL EXAMINED}

\section{Holotype}

Australia: Western Australia: , Blackjack, c. 75 km NNW. Tom Price, site HPRC0426, 2206'42.3"S, 117²4'54.4"E, 14 April-14 June 2011, subterranean trap, 40 m, D.C. Main, J.W. Quartermaine (WAM T119416)

\section{Paratypes}

Australia: Western Australia: 1, Champion, c. 75 km NNW. Tom Price, site HPRC0553, 2206'11.6"S, 117²7’46.2"E, 14 April 2011, stygofauna net, 22 m, J.S. Cocking, M.K. Curran (WAM T119417); 1 , c. 80 $\mathrm{km}$ NW. of Tom Price, bore HPRC2089, site FLI091, $22^{\circ} 07^{\prime} 52.9^{\prime \prime S}, 117^{\circ} 29^{\prime} 12.2^{\prime \prime E}, 24$ June 2010, J.S. Cocking, D.C. Main (WAM T108774); 1 , Homestead, $77.7 \mathrm{~km}$ NNW. of Tom Price, bore RHWRC0249P1-1, $22^{\circ} 04^{\prime} 42^{\prime \prime} \mathrm{S}, 117^{\circ} 25^{\prime} 31^{\prime \prime} \mathrm{E}, 29$ January 2010, scraping borehole, G. Humphreys (WAM T102542).

\section{DIAGNOSIS}

Anatemnus subvastus differs from all other species of the genus, except A. cavernicola, by the lack of eye-spots. It differs from $A$. cavernicola by the size and shape of the pedipalps, with A. subvastus with a pedipalpal femur length of 0.59-0.71 ( ), 0.64 ( ) mm, and A. cavernicola of 1.25 ( ) $\mathrm{mm}$. 


\section{DESCRIPTION}

\section{Adults}

Colour (Figures 2-7): carapace and pedipalps dark redbrown; coxae red-brown; abdomen and legs pale yellowbrown.

Setae and cuticle: setae long, mostly straight and acicular; most cuticular surfaces smooth and glossy, with exception of pedipalps, which are finely granulate.

Chelicera (Figure 11): much smaller than carapace length; surface smooth; cheliceral hand with 4 setae ( $s b s$ absent); movable finger with 1 sub-distal seta; all setae acuminate; seta $b s$ shorter than others; galea present, with several distal to sub-distal rami; with 2 dorsal and 1 ventral lyrifissures present; exterior condylar lyrifissure situated near exterior condyle; serrula interior connected to the cheliceral fixed finger for entire length, proximally modified to form velum; serrula exterior with 16 ( ), 17
( ) blades; lamina exterior present; rallum (Figure 12) with 4 blades, first two blades with anterior spinules, remainder smooth; rallum with basal and sub-basal blades shorter than others.

Pedipalps (Figures 9, 10): stout; lightly granulate on femur, patella, and at base of chelal fingers on prolateral face; setae acicular, straight or nearly so; trochanter with anterior margin rounded, with unmodified dorsal tubercle, 1.66-1.78 ( ), 1.79 ( ) x; femur cylindrical, robust, with 1 small trichobothrium on dorsal surface, situated near basal margin, 2.62-2.97 ( ), 2.72 ( ) x; patella cylindrical, robust, with narrow pedicel, with several small lyrifissures situated basally on dorsal surface, 2.11-2.44 ( ), 2.58 ( ) x; chelal hand cylindrical, external and internal chelal condyles small and rounded, chela (with pedicel) 2.97-3.21 ( ) longer than broad, 3.55 ( ) $x$, chela (without pedicel) 2.78-2.96 ( ), 3.38 ( ) $\mathrm{x}$; hand (without pedicel) 1.50-1.84 ( ), 2.03 ( ) x;
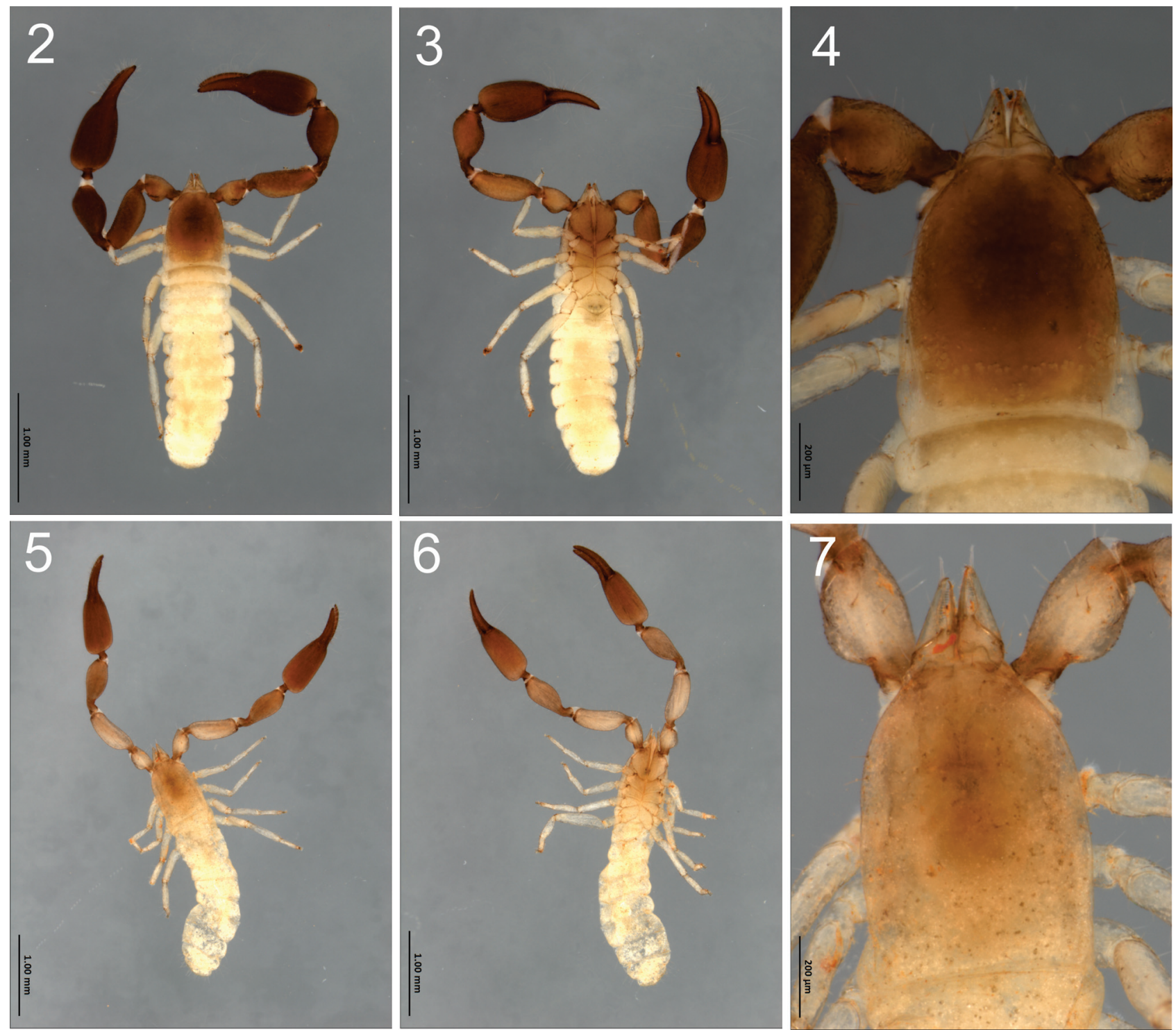
8

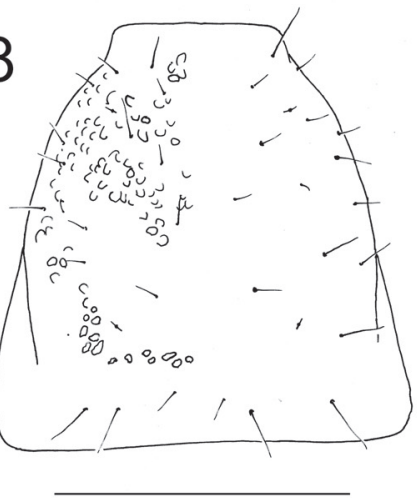

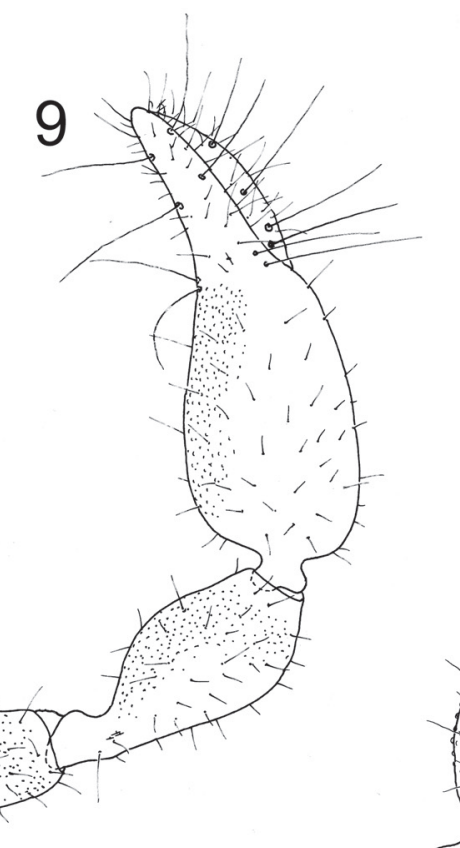
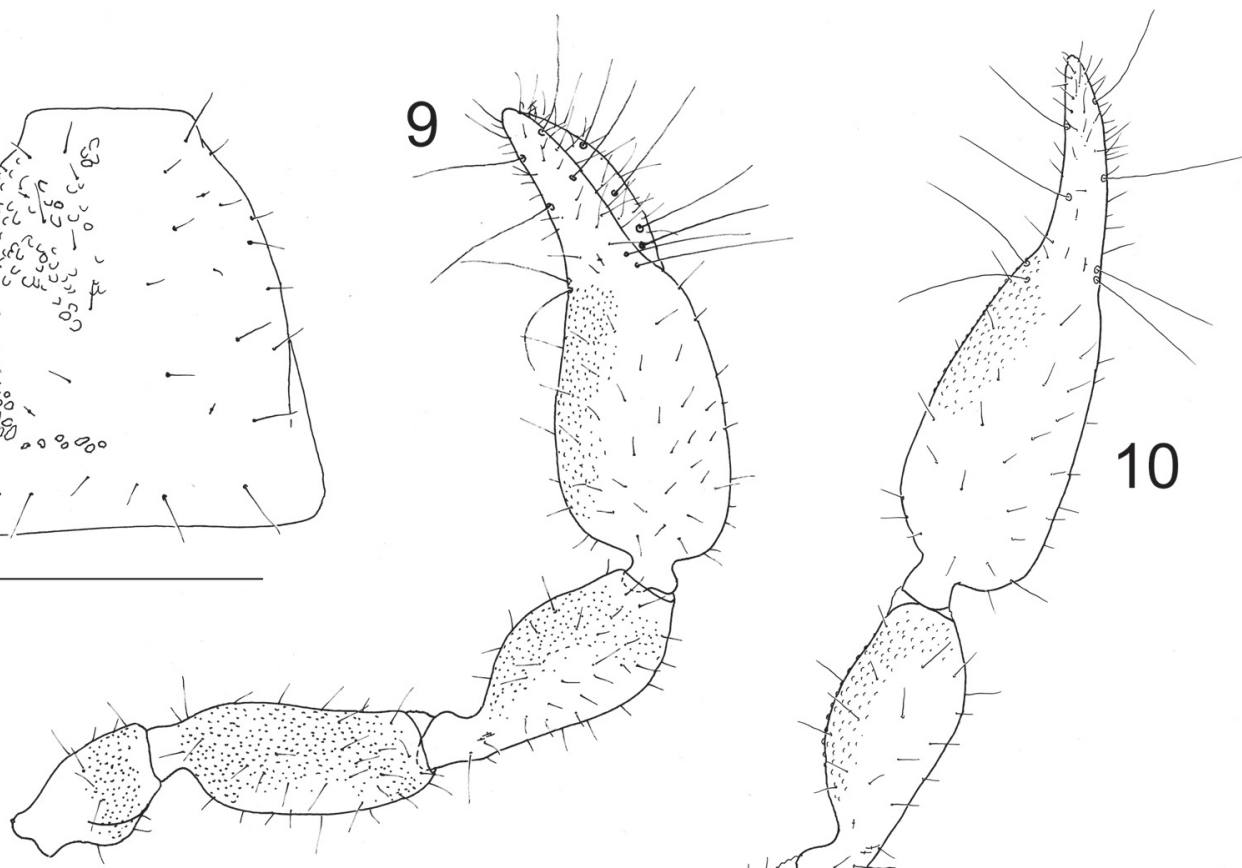

11
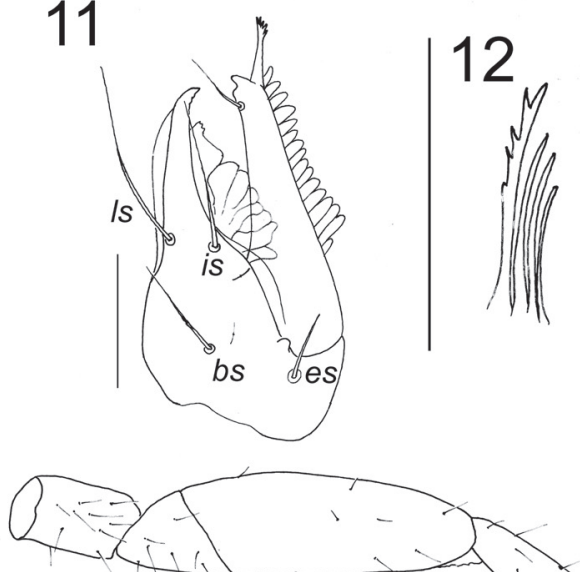

15

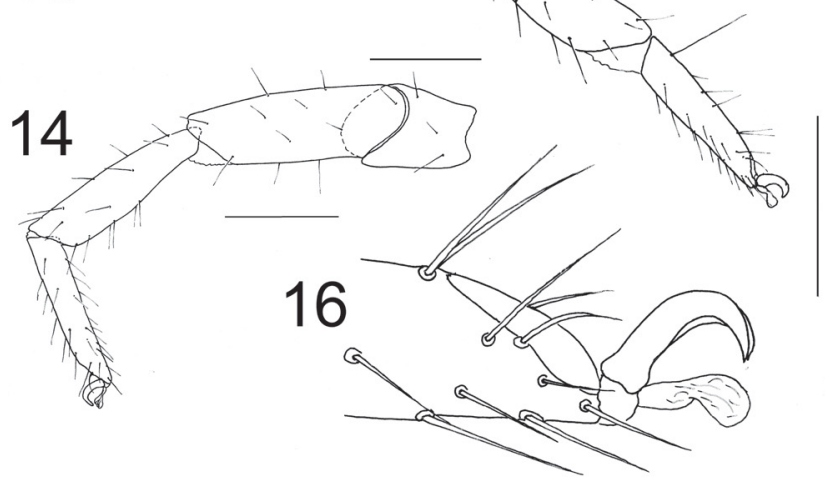

12

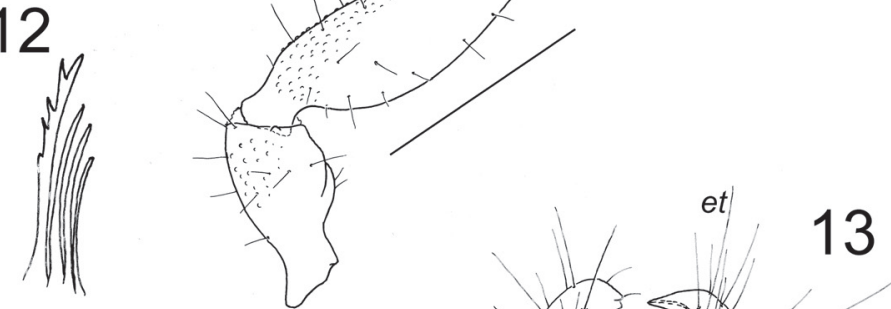

13

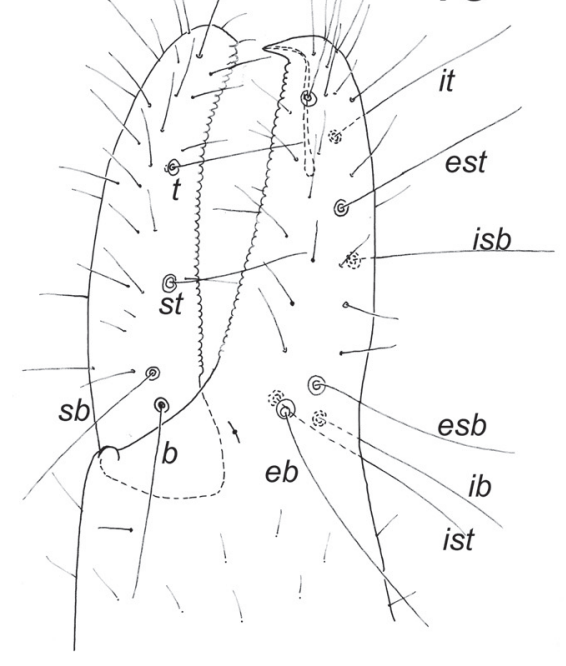

FIGURES 8-16 Anatemnus subvastus sp. nov., male holotype (WAMT119416), unless stated otherwise: 8, carapace, dorsal; 9, right pedipalp, dorsal; 10, right pedipalp, dorsal, female paratype (WAM T119417); 11, right chelicera, dorsal; 12, rallum; 13, left chelal fingers, lateral; 14, left leg I, lateral; 15, left leg IV, lateral; 16, tip of tarsus IV, lateral. Scale lines = $0.5 \mathrm{~mm}$ (Figures 8-10), $0.2 \mathrm{~mm}$ (Figure 13), $0.2 \mathrm{~mm}$ (Figures 14-15), 0.1 mm (Figures 11-12, 16). 

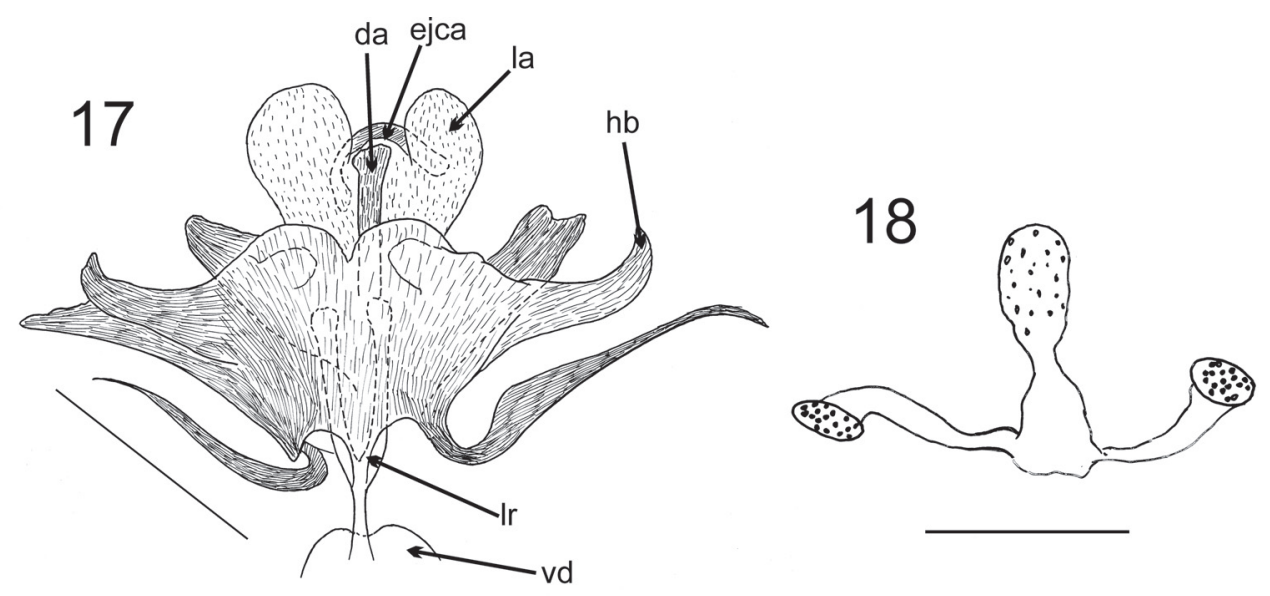

FIGURES 17-18 Anatemnus subvastus sp. nov.: 17, genitalia, ventral, male holotype (WAM T119416); 18, genitalia, ventral, female paratype (WAM T119417). Abbreviations: da, dorsal apodeme; ejca, ejaculatory canal atrium; hb, hooked branches; la, lateral apodemes; Ir, lateral rod; vd, ventral diverticulum. Scale lines $=0.1 \mathrm{~mm}$.

movable finger 0.75-0.95 ( ), 0.68 ( ) x longer than hand (without pedicel). Fixed finger with 8 trichobothria; movable finger with 4 trichobothria (Figure 13); $e b$ and $e s b$ situated at base of fixed finger on retrolateral face; $i b$ and ist situated at base of fixed finger on prolateral face; $i s b$ slightly proximad to est; it midway between et and est; et slightly distad to $i t ; s b$ much closer to $b$ than to $s t$; $s t$ midway between $s b$ and $t ; t$ acuminate. Both fingers straight in lateral view; chelal teeth juxtadentate; fixed finger with 37 ( ), 42 ( ) rounded teeth; movable finger with 46 ( ), 49 ( ) rounded teeth; accessory chelal teeth absent; venom apparatus present only in fixed chelal finger; venom duct long, terminating in nodus ramosus between et and est; nodus ramosus inflated; sense spots absent.

Cephalothorax: carapace (Figure 8) sub-rectangular; anterior margin medially indented; epistome absent; lateral margins evenly convex; $1.29-1.37$ ( ), 1.36 ( ) $x$ longer than broad, with 23-25 ( ), 23 ( ) setae including 4 on anterior margin and 4 on posterior margin; furrows absent; eyes absent. Manducatory process somewhat pointed, with 2 apical setae and 1 sub-oral seta; maxilla with 20 ( ), 16 ( ) other setae; maxillary shoulder absent; median maxillary lyrifissure present, situated medially, strongly curved, U-shaped; posterior maxillary lyrifissure present, strongly curved. Coxa I about same width as coxa IV; coxae I-IV setal formula: , 8: 6: 5: 10; , 7: 7: 5: 14 .

Legs (Figures 14, 15): femora I and II about same size as patellae I and II, respectively; junction between anterior femora and patellae oblique; junction between posterior femora and patellae strongly angulate; femora III and IV much smaller than patellae III and IV, respectively; femur + patella IV 3.48-3.86 ( ),
4.14 ( ) x longer than broad; tibiae III and IV without tactile seta; tarsi III and IV with long tactile seta, situated basally; tarsal lyrifissure lying flush with tarsal surface; subterminal tarsal seta curved; claws smooth; arolium slightly shorter than claws; arolium not divided (Figure 16).

Abdomen: tergites straight; not divided; tergites, setal formula , 6: 6: 6: 9: 10: 8: 9: 10:11: 13:12: 2; , 5: 4: 6: 7: 8: 9: 8: 8: 10: 12: 15: 2; arranged in single rows; lateral margin of tergites not modified; sternites, setal formula , 11: (1) 6 (1): (1) 6 (1): 9: 9: 10: 10: 10: 10: 13: 2 ; sternites, setal formula , 11: (1) 7 (1): (1) 6 (1): 10: 10: 9: 10: 10: 11: 13: 2; glandular setae absent; medial sternites without suture line; pleural membrane uniformly longitudinally striate; without setae; stigmatic helix present; anus (tergite XII and sternite XII) without raised rim; anus situated between tergite XI and sternite XI.

Genitalia: male: dorsal apodeme long with rounded apex, ejaculatory canal atrium broad, lateral apodemes spherical, lateral rods Y-shaped with rounded apices, hooked branches wide (Figure 17), genital atrium without glandular setae; female (Figure 18): with single anteriorly directed spermathecal lobes, and 1 pair of small lateral cribriform plates.

Dimensions (mm): Males: holotype followed by other males (where applicable): Body length 2.58 (2.24-2.66). Chelicera 0.241/0.152; movable finger length 0.195 . Pedipalp: trochanter $0.385 / 0.218(0.371-0.382 / 0.215-$ $0.223)$; femur $0.652 / 0.248(0.589-0.712 / 0.225-0.240)$; patella $0.650 / 0.289(0.637-0.662 / 0.271-0.302)$; chela (with pedicel) 1.139/0.382 (1.132-1.162/0.362-0.381); chela (without pedicel) length 1.066 (1.058-1.072); chelal hand (without pedicel) length 0.704 (0.573-0.595); 
movable finger length $0.531(0.470-0.542)$. Carapace $0.715 / 0.543(0.710-0.742 / 0.518-0.576)$. Leg I: femur $0.228 / 0.144$; patella $0.376 / 0.127$; tibia $0.323 / 0.084$; tarsus $0.296 / 0.052$. Leg IV: femur + patella $0.637 / 0.183(0.571-$ 0.618/0.153-0.160); tibia 0.458/0.118; tarsus 0.309/0.072.

Female: paratype (WAM T119417): Body length 2.83. Chelicera $0.261 / 0.133$; movable finger length 0.185 . Pedipalp: trochanter $0.377 / 0.211$; femur $0.642 / 0.236$; patella $0.680 / 0.264$; chela (with pedicel) 1.264/0.356; chela (without pedicel) 1.208; hand (without pedicel) 0.724 ; movable finger length 0.495 . Carapace $0.778 / 0.572$. Leg I: femur $0.212 / 0.123$; patella $0.353 / 0.097$; tibia $0.328 / 0.051$; tarsus $0.295 / 0.049$. Leg IV: femur + patella $0.633 / 0.153$; tibia $0.459 / 0.085$; tarsus $0.315 / 0.063$.

\section{REMARKS}

Anatemnus subvastus has been collected from a very small area of the central Pilbara in the Hamersley Range, less than $20 \mathrm{~km}^{2}$. All four specimens were collected from subterranean environments either using baited subterranean fauna traps, or by scraping the sides of the boreholes with a net. The specimens lack eye spots and are notably paler than epigean species of the genus (M. Burger, M. Harvey, personal observations). There is some notable variation in the size and proportions of the pedipalps and legs between the samples collected. For example, the pedipalpal femur is $0.59-0.71(\mathrm{)}, 0.64(\mathrm{)}) \mathrm{mm}$ in length and 2.62-2.97 ( ), 2.72 ( ) x longer than broad, the pedipalpal patella is $0.64-0.66($ ), 0.68 ( ) $\mathrm{mm}$ in length and 2.11-2.44 ( ), 2.58 ( ) x longer than broad, and the chela (without pedicel) is 1.13-1.16 ( ), 1.21 ( ) $\mathrm{mm}$ in length and 2.78-2.96 ( ), 3.38 ( ) x longer than broad. However, as the specimens come from a small area, we prefer to attribute this to intraspecific variation.

This species represents only the second troglobitic species of the genus. The first, A. cavernicola, from Jump Up Cave, in the Grey Range in north-western New South Wales, is substantially larger than A. subvastus, with a pedipalpal femur length of $1.25 \mathrm{~mm}$ (Beier 1976).

The subterranean fauna of the immediate area contains several other confirmed troglobites, including undescribed species of Draculoides and Paradraculoides (Schizomida, Hubbardiidae), Lagynochthonius and Tyrannochthonius (Pseudoscorpiones, Chthoniidae), Dalodesmidae (Diplopoda, Polydesmida) (C.A. Car, personal communication) and Cormocephalus (Scolopendrida, Scolopendridae) (J.M. Waldock, personal communication).

\section{ETYMOLOGY}

The species name refers to the presence of this species in subterranean environments in the semi-arid Pilbara region of Western Australia (sub-, Latin, under; vastus, Latin, waste, desert).

\section{ACKNOWLEDGEMENTS}

We are very grateful to staff of Bennelongia Environmental Consultants for supplying some of the specimens used in this study, in particular Stuart Halse, Dean Main, Jeremy Quartermaine, Jim Cocking and Michael Curran. We also thank Garth Humphreys of Biota Environmental Sciences, collector of the initial specimen. Funds to support MAAB were supplied by RioTinto and facilitated by Caitlin O'Neill and Sam Luccitti.

\section{REFERENCES}

Baehr, B.C., Harvey, M.S., Burger, M. and Thoma, M. (2012). The new Australasian goblin spider genus Prethopalpus (Araneae, Oonopidae). Bulletin of the American Museum of Natural History 763: 1-113.

Beier, M. (1932a). Revision der Atemnidae (Pseudoscorpionidea). Zoologische Jahrbücher, Abteilung für Systematik, Ökologie und Geographie der Tiere 62: 547-610.

Beier, M. (1932b). Pseudoscorpionidea II. Subord. C. Cheliferinea. Tierreich 58: i-xxi, 1-294.

Beier, M. (1940). Die Pseudoscorpionidenfauna der landfernen Inseln. Zoologische Jahrbücher, Abteilung für Systematik, Ökologie und Geographie der Tiere 74: 161-192.

Beier, M. (1944). Über Pseudoscorpioniden aus Ostafrika. Eos, Madrid 20: 173-212.

Beier, M. (1948). Über Pseudoscorpione der australischen Region. Eos, Madrid 24: 525-562.

Beier, M. (1951a). Die Pseudoscorpione Indochinas. Mémoires du Muséum National d'Histoire Naturelle, Paris, nouvelle série 1: 47-123.

Beier, M. (1951b). On some Pseudoscorpionidea from Kilimanjaro. Annals and Magazine of Natural History (12) 4: 606-609.

Beier, M. (1952). On some Pseudoscorpionidea from Malaya and Borneo. Bulletin of the Raffles Museum 24: 96-108.

Beier, M. (1954). Report from Prof. T. Gislén's expedition to Australia in 1951-1952. 7. Pseudoscorpionidea. Acta Universitatis Lundensis, nova series (2) 50: 1-26.

Beier, M. (1957). Pseudoscorpionida. Insects of Micronesia 3(1): $1-64$.

Beier, M. (1959). Zur Kenntnis der PseudoscorpionidenFauna Afghanistans. Zoologische Jahrbücher, Abteilung für Systematik, Ökologie und Geographie der Tiere 87: 257-282.

Beier, M. (1965). Die Pseudoscorpioniden Neu-Guineas und der benachbarten Inseln. Pacific Insects 7: 749-796.

Beier, M. (1966). On the Pseudoscorpionidea of Australia. Australian Journal of Zoology 14: 275-303.

Beier, M. (1976). A cavernicolous atemnid pseudoscorpion from New South Wales. Journal of the Australian Entomological Society 15: 271-272.

Beier, M. and Turk, F.A. (1952). On two collections of Cyprian Pseudoscorpionidea. Annals and Magazine of Natural History (12) 5: 766-771.

Burger, M., Harvey, M.S. and Stevens, N. (2010). A new species of blind subterranean Tetrablemma (Araneae: Tetrablemmidae) from Australia. Journal of Arachnology 38: $146-149$. 
Chamberlin, J.C. (1931). The arachnid order Chelonethida. Stanford University Publications, Biological Sciences 7(1): $1-284$.

Chamberlin, J.C. (1939). New and little-known false scorpions from the Marquesas Islands (Arachnida: Chelonethida). Bulletin of the Bernice P. Bishop Museum 142: 207-215.

Dallwitz, M.J., Paine, T.A. and Zurcher, E.J. (1999 onwards). User's guide to the DELTA editor. CSIRO. http://deltaintkey.com/www/delta-ed.htm. Accessed 20 October 2014.

Eberhard, S.M., Halse, S.A. and Humphreys, W.F. (2005). Stygofauna in the Pilbara region, north-west Western Australia: a review. Journal of the Royal Society of Western Australia 88: 167-176.

Edward, K.L. and Harvey, M.S. (2008). Short-range endemism in hypogean environments: the pseudoscorpion genera Tyrannochthonius and Lagynochthonius (Pseudoscorpiones: Chthoniidae) in the semiarid zone of Western Australia. Invertebrate Systematics 22: 259-293.

Halse, S.A. and Pearson, G.B. (2014). Troglofauna in the vadose zone: comparison of scraping and trapping results and sampling adequacy. Subterranean Biology 13: 17-34.

Harvey, M.S. (1992). The phylogeny and classification of the Pseudoscorpionida (Chelicerata: Arachnida). Invertebrate Taxonomy 6: 1373-1435.

Harvey, M.S. (2013). Pseudoscorpions of the World, version 3.0. Western Australian Museum, Perth. http://museum.wa.gov. au/catalogues-beta/pseudoscorpions. Accessed 20 October 2014.

Harvey, M.S., Berry, O., Edward, K.L. and Humphreys, G. (2008). Molecular and morphological systematics of hypogean schizomids (Schizomida: Hubbardiidae) in semiarid Australia. Invertebrate Systematics 22: 167-194.

Harvey, M.S. and Edward, K.L. (2007). A review of the pseudoscorpion genus Ideoblothrus (Pseudoscorpiones, Syarinidae) from western and northern Australia. Journal of Natural History 41: 445-472.

Harvey, M.S. and Leng, M.C. (2008a). Further observations on Ideoblothrus (Pseudoscorpiones: Syarinidae) from subterranean environments in Australia. Records of the Western Australian Museum 24: 379-386.

Harvey, M.S. and Leng, M.C. (2008b). The first troglomorphic pseudoscorpion of the family Olpiidae (Pseudoscorpiones), with remarks on the composition of the family. Records of the Western Australian Museum 24: 387-394.
Harvey, M.S., Ratnaweera, P.B., Udagama, P.V. and Wijesinghe, M.R. (2012). A new species of the pseudoscorpion genus Megachernes (Pseudoscorpiones: Chernetidae) associated with a threatened Sri Lankan rainforest rodent, with a review of host associations of Megachernes. Journal of Natural History 46: 2519-2535.

Harvey, M.S. and Volschenk, E.S. (2007). The systematics of the Gondwanan pseudoscorpion family Hyidae (Pseudoscorpiones: Neobisioidea): new data and a revised phylogenetic hypothesis. Invertebrate Systematics 21: 365-406.

Judson, M.L.I. (2007). A new and endangered species of the pseudoscorpion genus Lagynochthonius from a cave in Vietnam, with notes on chelal morphology and the composition of the Tyrannochthoniini (Arachnida, Chelonethi, Chthoniidae). Zootaxa 1627: 53-68.

Klausen, F.E. (2005). The male genitalia of the family Atemnidae (Pseudoscorpiones). Journal of Arachnology 33: 641-662.

Mahnert, V. (1978). Pseudoskorpione (ausgenommen Olpiidae, Garypidae) aus Congo-Brazzaville (Arachnida, Pseudoscorpiones). Folia Entomologica Hungarica 31: 69-133.

Morikawa, K. (1968). On some pseudoscorpions from Rolwaling Himal. Journal of the College of Arts and Sciences, Chiba University 2: 259-263.

Muchmore, W.B. (1972). A phoretic Metatemnus (Pseudoscorpionida, Atemnidae) from Malaysia. Entomological News 83: 11-14.

Murthy, V.A. and Ananthakrishnan, T.N. (1977). Indian Chelonethi. Oriental Insects Monograph 4: 1-210.

Redikorzev, V. (1938). Les pseudoscorpions de l'Indochine française recueillis par M. C. Dawydoff. Mémoires $d u$ Muséum National d'Histoire Naturelle, Paris 10: 69-116.

Sivaraman, S. (1980). Pseudoscorpions from South India: some new species of the family Atemnidae Chamberlin (Pseudoscorpionida: Monosphyronida). Oriental Insects 14: 345-362.

Vachon, M. (1938). Voyage en A.O.F. de L. Berland et J. Millot. IV. Pseudoscorpions. Première note. Atemnidae. Bulletin de la Société Zoologique de France 63: 304-315.

MANUSCRIPT RECEIVED 24 OCTOBER 2014; ACCEPTED 2 DECEMBER 2014. 